\title{
Research on the target power level for Li-air battery and weight ratio distribution in a dual-battery vehicle system with Li-ion battery
}

\author{
Jijie Xu, Su Zhou \\ School of Automotive Studies, Tongji University, Shanghai, China \\ xu_jijie@126.com, suzhou@tongji.com
}

Keywords: dual automotive battery model, gravimetric power density, ultra-high energy storage

\begin{abstract}
Li-air battery is considered as a promising alternative in the future to replace the current battery technologies. It can eliminate the common range anxiety in electric vehicles for its compelling high energy density. However the extremely low power density becomes its deadly drawback which makes it unsuitable for automobile application. In this article, we built a dualbattery model with a high power density Li-ion battery and a high energy density Li-air battery to investigate the potential of this hybrid solution and tried to get a reference value about the target for the resistance and power density of Li-air battery in the following years. After tests we've got a conclusion that with a total dual-battery weight at $300 \mathrm{~kg}$, an average resistance around $0.015 \Omega$ per cell which correspondingly leads to the power density $65 \mathrm{~kW} / \mathrm{kg}$ in a pack level could be suggested as a minimal target for Li-air battery. The optimal choice of weight ratio between two batteries is essential for the power design of Li-air battery.
\end{abstract}

\section{Introduction}

Nowadays, electrical vehicle (referred to as 'EV' below) has been widely recognized by public for its clean renewable energy and huge efficiency.Nevertheless, before a large scale application, it still needs to conquer many fundamental challenges, one of which should be its poor range performance. This range issue is ascribed to the capacity shortage of batteries.

For now, Li-ion battery has been chosen as the most appropriate battery solution for EVs. Its common anode is solid carbon or graphite while many cathode materials are available. But whatever the cathode material it uses, the state of the art energy density of Li-ion battery in a cell level is no more than $200 \mathrm{Wh} / \mathrm{kg}$ [1] and it's hard to make a significant improvement in the future. Then to find another battery technology with a higher energy density becomes an urgent mission for EVs.

Li-air battery appears to be such a capable candidate. It has a specific energy significantly higher than current lithium-ion batteries for the cathode oxidizing agent inside is oxygen from ambient air which doesn't need to be stored in the battery. The energy calculations has showed that an energy density value as $1000 \mathrm{Wh} / \mathrm{kg}$ or more in a cell level should be attainable if several fundamental challenges can be overcome [2]. Unfortunately the power density of this battery is extremely low [3], which are far away from the standard for automobile field. Cell impedance must be significantly reduced to achieve an adequate power density.

The fact that characteristics between Li-ion battery and Li-air battery are totally reverse inspires us to try to take the advantage of each other. In the course of the European research project 'SuperLIB' [4], a concept for a dual operation mode of both high energy and high power battery cell technology was studied. Similarly a dual-battery model is built in this text by using a high energy density Li-air battery and a high power density Li-ion battery simultaneously to analyze the possibility and potential advantages of this hybrid solution.

\section{Model Description}

Here we employ the AVL-software CRUISE to set up a full vehicle model. The schematic diagram of the vehicle components connection is displayed as Fig. 1. Mechanical connection part is comprised of wheels, brakes, a differential, a final drive and a permanent magnetic synchronous 
motor (referred to as 'EM' below) which works as the power unit. Two batteries are arranged in parallel as the vehicle energy source.

Another software Simulink is recruited to generate the battery control strategy as a co-simulation tool with CRUISE. The strategy aims at an optimized utilization of the Li-air technology in an automotive environment. The Li-air battery

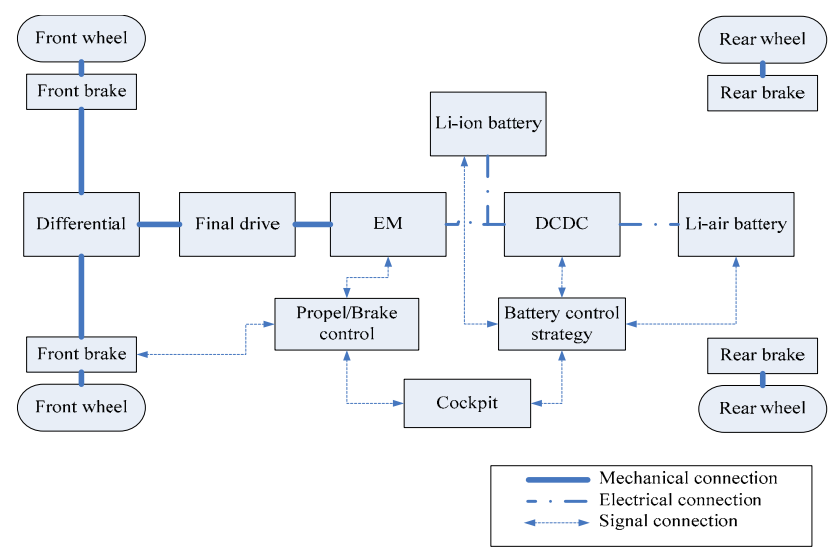

Figure 1. Schematic illustration of vehicle model in CRUISE.

TABLE I. VEHICLE SPECIFICATIONS

\begin{tabular}{|c|c|c|}
\hline \multirow{2}{*}{ Battery } & Type & Li-ion and Li-air battery \\
\hline & The other information & Detailed in Chapter 3 \\
\hline \multirow{4}{*}{ Motor } & Type & $\begin{array}{l}\text { Permanentmagnetic synchronous } \\
\text { motor }\end{array}$ \\
\hline & $\begin{array}{l}\text { Nominal voltage } \\
\text { (voltage range) }\end{array}$ & $\begin{array}{c}320 \mathrm{~V} \\
(200 \mathrm{~V} \sim 420 \mathrm{~V})\end{array}$ \\
\hline & Maximal power & $75 \mathrm{~kW}$ \\
\hline & Maximal torque@motor speed & 240 Nm@0-3000 rpm \\
\hline \multirow{5}{*}{$\begin{array}{l}\text { Whole } \\
\text { Vehicle }\end{array}$} & Vehicle type & Pure EV \\
\hline & Drive mode & FWD \\
\hline & Wheel base & $2467 \mathrm{~mm}$ \\
\hline & Curb and gross weight & $1500 \mathrm{~kg}, 1800 \mathrm{~kg}$ \\
\hline & Transmission ratio & 6.058 \\
\hline
\end{tabular}

discharges at a constant current that is limited by the cut-off voltage. Meanwhile the Li-ion battery will act as an extra energy supply when the demand power from EM side is beyond the reach of Liair battery, which will frequently occur given the Li-air battery's low power. As a result of that the strategy shall always focus on keeping the Li-ion battery operational as long as possible. Li-ion battery will be constantly recharged by Li-air side during low speed driving and through the regenerative braking as well.

In Table I is an overview of configurations implemented in our vehicle model.

\section{Methodology}

With the help of present studies the power capability of Li-ion cell technology and the ultra-high energy density of Li-air cell technology can be utilized in parallel, given sufficient maturity of the technology. 


\section{A. Li-air cell resistance selection}

As Li-air battery is still in its technological infancy, a detailed cell specification comparable to state-of-the-art info for Li-ion technology is not quite available. Here we simplify the impedance into a whole pure ohmic resistance, leaving out the details on the overvoltage and the other impendence factors.

Note that only lab-scale cell testing is procurable in present researches. A resistance value of 165 $\Omega \cdot \mathrm{cm}^{2}$ [5] is deduced in Monaco's paper. Using this value under the assumption of an overall cell surface of approximate $560 \mathrm{~cm}^{2}$ [6], it comes up to an estimated state-of-the-art resistance of approx. $0.3 \Omega$ for use. Starting with $0.3 \Omega$, the test resistance points are selected with decreasing difference. The terminal value $0.015 \Omega$ is determined by the results which will be discussed later in Chapter 4 . The array below shows the resistance values selected for the study:

Resistance $=[0.3,0.2,0.1,0.075,0.05,0.04,0.03,0.02,0.015]$. (Unit: $\Omega$ )

A series of experiments will then be carried out to find the minimal requirement for the Li-air battery to be capable

TABLE II. CELLSPECIFICATIONS[8]

\begin{tabular}{|c|c|c|}
\hline Cell Type & Li-air & Li-ion \\
\hline Cell Capacity & $322 \mathrm{AH}$ & $40 \mathrm{AH}$ \\
\hline Nominal Voltage & $3.1 \mathrm{~V}$ & $3.65 \mathrm{~V}$ \\
\hline Minimal Voltage & $2.7 \mathrm{~V}$ & $2.5 \mathrm{~V}$ \\
\hline Maximal Voltage & $4.2 \mathrm{~V}$ & $4.2 \mathrm{~V}$ \\
\hline Cell Weight & $1.813 \mathrm{~kg}$ & $1.422 \mathrm{~kg}$ \\
\hline
\end{tabular}

in a hybrid solution with Li-ion battery. The power performance will be reflected by these different resistances consequently.

\section{B. Battery configuration}

The required parameters of Li-air system is deduced from findings in the course of the EU research project LABOHR[7]. And nickel manganese cobalt oxide material (NMC) has been adopted for our Li-ion battery for its high voltage and capacity. Its parameters are based on AVL-internal test results. Note that the values of cell weight and volume are averagely calculated from a battery pack including all essential accessories (Table II).

\section{Battery sizing}

In a given total weight, we assign the ratio between above two batteries and run these distribution solutions in different $\mathrm{Li}$-air cell resistance values to evaluate corresponding results.

According to the survey on current vehicles on the market, here we investigate the battery system configurations with a total weight in the range of $300 \mathrm{~kg}$. During the design process, for some limitations such as the net voltage requirement of electrical motor and the cell number in series and parallel, it's impossible to realize some specific weight distribution and make the total battery weight of all samples precisely equal. Small weight deviation range is $\pm 0.5 \%$, i.e.

$$
300 * 99.5 \%<W_{\text {Li-air }}+W_{\text {Li-ion }}<300 * 100.5 \% \text { (1) }
$$

$\mathrm{W}_{\mathrm{Li}-\text {-air }}$ and $\mathrm{W}_{\mathrm{Li} \text {-ion }}$ : the weight of Li-air and Li-ion battery.

The total cell number $\left(\mathrm{N}_{\text {total }}\right)$ in a battery, which is a multiplication between the cell number in series $\left(n_{s}\right)$ and in parallel $\left(n_{p}\right)$, can also be obtained by the total battery weight dividing the single cell weight $\left(\mathrm{w}_{\mathrm{LL}-\mathrm{ion}}\right)$. For Li-ion battery is directly connected to the electrical motor side, the voltage of Li-ion battery $\left(\mathrm{U}_{\mathrm{Li} \text {-ion }}\right)$ will be limited by the range of EM voltage $\left(\mathrm{U}_{\text {motor }}\right)$. The range of Li-ion cell number in series and in parallel can then be deduced with (2).

$$
\left\{\begin{array}{l}
N_{\text {total }}=n_{s} * n_{p}=\frac{W_{\text {Li-ion }}}{w_{\text {LI-ion }}} \\
U_{\text {Li-ion }}=U_{\text {cell }} * n_{s} \\
U_{\text {motor } \min }<U_{\text {Li-ion }}<U_{\text {motor } \max }
\end{array}\right.
$$


$\mathrm{U}_{\text {cell_ion }}$ : single cell voltage of Li-ion;

$\mathrm{U}_{\text {motor?min }}$ and $\mathrm{U}_{\text {motormax }}$ : the maximal and minmimal voltage of EM.

TABLE III. SETS FOR USE

\begin{tabular}{|c|c|c|c|c|c|c|}
\hline No. & Battery & $\mathrm{N}_{\text {total }}$ & $\mathrm{n}_{\mathrm{s}}$ & $\mathrm{n}_{p}$ & Weight (kg) & Total Weight (kg) \\
\hline \multirow{2}{*}{ Set 1} & Li-ion & 60 & 60 & 1 & 85.32 & \multirow{2}{*}{299.25} \\
\hline & Li-air & 118 & 59 & 2 & 213.93 & \\
\hline \multirow{2}{*}{ Set 2} & Li-ion & 70 & 70 & 1 & 99.54 & \multirow{2}{*}{298.97} \\
\hline & Li-air & 110 & 55 & 2 & 199.43 & \\
\hline \multirow{2}{*}{ Set 3} & Li-ion & 88 & 88 & 1 & 125.14 & \multirow{2}{*}{299.18} \\
\hline & Li-air & 96 & 96 & 1 & 174.05 & \\
\hline \multirow{2}{*}{ Set 4} & Li-ion & 100 & 100 & 1 & 142.20 & \multirow{2}{*}{299.79} \\
\hline & Li-air & 87 & 87 & 1 & 157.73 & \\
\hline \multirow{2}{*}{ Set 5} & Li-ion & 122 & 61 & 2 & 173.48 & \multirow{2}{*}{300.39} \\
\hline & Li-air & 70 & 70 & 1 & 126.91 & \\
\hline \multirow{2}{*}{ Set 6} & Li-ion & 140 & 70 & 2 & 199.08 & \multirow{2}{*}{300.61} \\
\hline & Li-air & 56 & 56 & 1 & 101.53 & \\
\hline \multirow{2}{*}{ Set 7} & Li-ion & 158 & 79 & 2 & 224.68 & \multirow{2}{*}{299.01} \\
\hline & Li-air & 41 & 41 & 1 & 74.33 & \\
\hline \multirow{2}{*}{ Set 8} & Li-ion & 176 & 88 & 2 & 250.27 & \multirow{2}{*}{299.22} \\
\hline & Li-air & 27 & 27 & 1 & 48.95 & \\
\hline \multirow{2}{*}{ Set 9} & Li-ion & 210 & 70 & 3 & 298.62 & \multirow{2}{*}{298.62} \\
\hline & Li-air & 0 & 0 & 0 & 0 & \\
\hline
\end{tabular}

There is no strict law to the number in series and in parallel in Li-air battery side. But for the efficiency and realizability of DC/DC, the voltage of Li-air battery is decided to be as close as possible to the voltage of the LI-ion battery side. Here we give a coefficient $\alpha=0.4$ to limit the voltage of Li-air battery if applicable (Set 7 and set 8 below are exceptions).

$$
(1-\alpha) * U_{\text {Li-ion_nominal }}<U_{\text {Li-air_nominal }}<(1+\alpha) * U_{\text {Li-ion_nominal }}
$$

'Nominal' in the equation means the values in nominal condition are used. The same method with Li-ion battery can be used to get cell number of Li-air battery in series and parallel.

After applying above equations, we choose nine sets as illustrated in Table III. The information of every set from left to right in turn includes the battery type, the battery's corresponding total cell number, cell number in series and parallel, a single battery weight and the total weight of two batteries.

\section{Results analysis}

New European Driving Cycle (NEDC) and American Highway fuel economy test (HWFET) have been selected for the present study. NEDC is a typical city driving condition in Europe and HWFET is a consistent high speed driving cycle. Through these two cycles we can achieve the vehicle performance in different environment.

The simulations have been performed in a SOC (Abbreviation for the battery's state of charge) window between 95\% SOC and 18\% SOC. The end value $18 \%$ is decided for the consideration of the battery cycle life. If the SOC of Li-ion battery comes to $18 \%$ first, the simulation will stop immediately for Li-air battery can't fulfil the driving requirement alone for its poor power.

The outcomes are listed as follows. (Note that we use the symbol ' $R$ 'below as the abbreviation for the Li-air cell resistance)

\section{Power density and energy density}

The trend of the power density in Li air battery verse its resistance is like a hyperbolic curve (Fig. 2). This relationship can be deduced straightforward from the basic power equation since the circuit 
is simplified with only a pure resistor element. The highest power density at is $66.27 \mathrm{~W} / \mathrm{kg}$, and the lowest at is $3.31 \mathrm{~W} / \mathrm{kg}$.

The average energy density of two batteries linearly increases with the weight of Li-air battery (Fig. 3). The energy density in set 1 is $422 \mathrm{Wh} / \mathrm{kg}$, and the lowest is $103 \mathrm{Wh} / \mathrm{kg}$. Though $422 \mathrm{Wh} / \mathrm{kg}$ is far away from the theoretical energy density of Li-air battery, it's already a pleasing value for current development.

\section{E. NEDC results}

In NEDC driving cycle three kinds of trends can be observed: (Fig.4):

1. When $\mathrm{R} \leq 0.02 \Omega$, the range has a quasi-linear increase with the Li-air battery weight.

2. When $0.03 \Omega \leq \mathrm{R} \leq 0.05 \Omega$, the range still ascends, but the rule is not that regular.

3. When $\mathrm{R} \geq 0.075 \Omega$, the range will decrease with Li-air battery weight.

The diverse SOC performance of Li-air battery in the corresponding situation can give an explicit explanation to these diverse scenarios (Fig.5).
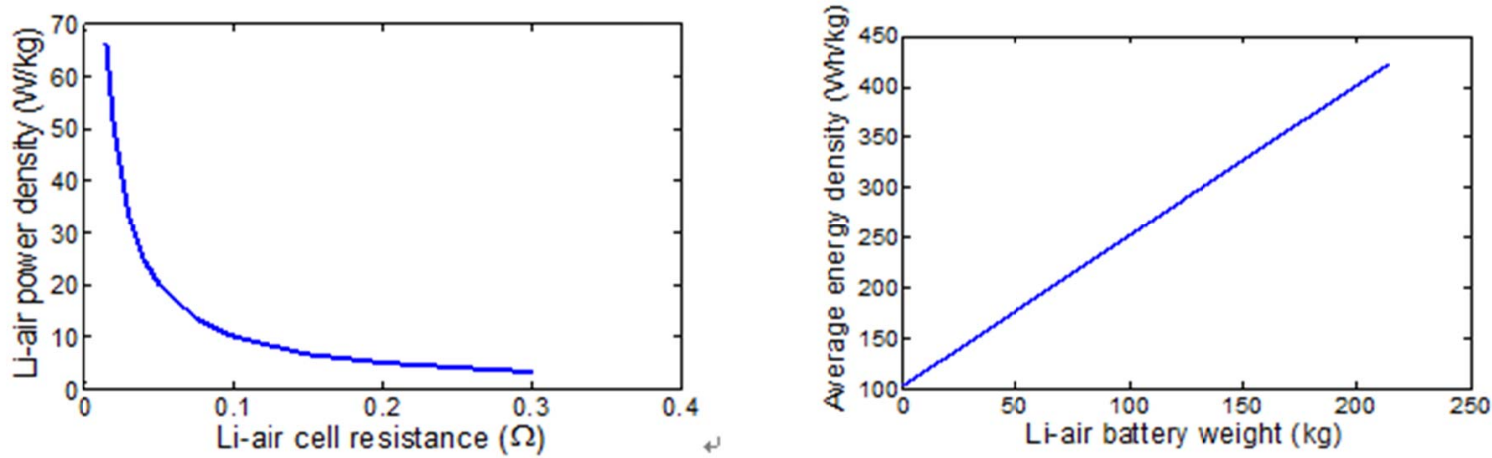

Figure 2. Power density trend of Li-air battery Figure3. Average energy density of dualbattery system

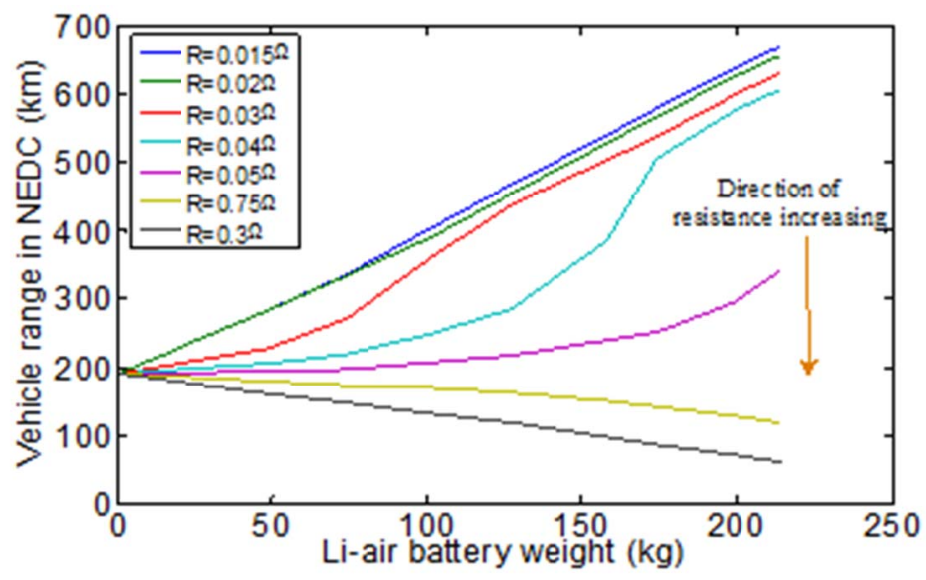

Figure 4.Vehicle range inNEDC

In case 1 , both the Li-air and Li-ion battery will be discharged fully to the cut-off condition in every weight distribution. For the energy density of the Li-air battery never changes, the total energy used which determines the final range is just right linearly related to the weight ratio.

In case 2 , the capacity usage of Li-air battery is gradually approaching to the maximum with the increase of its weight. When at a relatively low weight, the Li-air battery can't provide sufficient power to assist vehicle acceleration and Li-ion battery charging, making Li-ion battery quickly used up as the major energy source. Thus the Li-air battery system needs to be scaled up in terms of weight and energy so that the power output is sufficient for assisting the Li-ion battery (similar to case 1 , only when $\mathrm{R}=0.03 \Omega$ and $\mathrm{R}=0.04 \Omega$ ). Note that Li-air battery still has some capacity remaining when $\mathrm{R}=0.05 \Omega$ in set 1 condition.

In case3, it's an unsatisfying situation, which unfortunately fits the rule incurrent Li-air battery developmental level. The power of Li-air battery is so negligible that increasing its weight which causes the energy reduction of Li-ion battery will also lead to a less usage of Li-air battery. It has an 
adverse impact to put more weight to the Li-air battery side. It makes no much sense to implement such a hybrid solution if Li-air battery will keep hovering in this level.

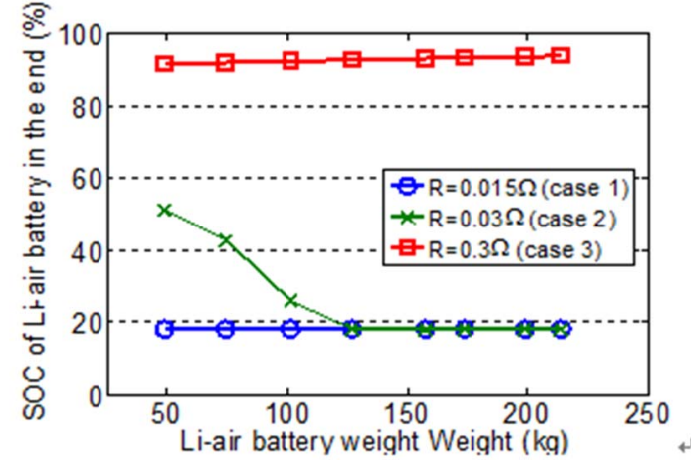

Figure 5.SOC Trends in NEDC

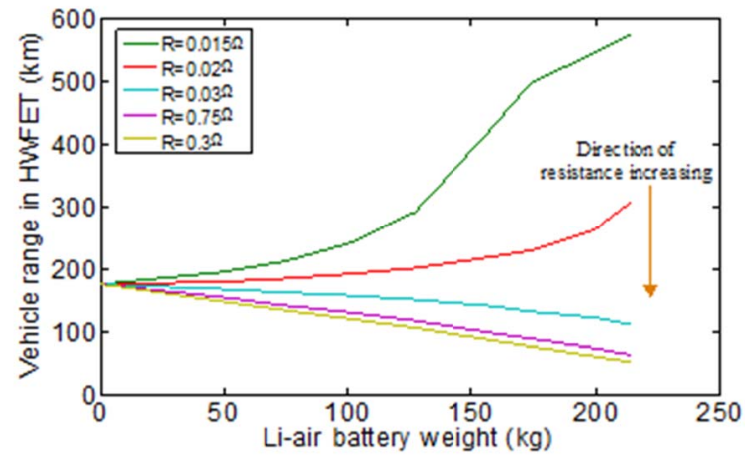

Figure 6.Vehicle range in HWFET

\section{F. HWFET results}

For the HWFET driving cycle needs a relatively constant and high current from battery side for a nonstop driving, it leaves no much time for Li-air battery to recharge Li-ion battery side. This feature makes the driving task severer.

There are simply two rules in HWFET driving cycle(Fig.6), similar to the case 2 and 3 in NEDC. Only in the situation when with a large Li-air battery weight can LI-air battery be fully discharged (the SOC trend is similar to the case 2 in NEDC driving cycle). When $\mathrm{R} \geq 0.02 \Omega$, Li-air battery didn't fulfil its mission as the same reason already analyzed in NEDC driving cycle.

From the analysis above, now we can take $0.015 \Omega$ as the minimal resistance requirement for every cell in the Li-air battery. The power density comes to $66.27 \mathrm{Kw} / \mathrm{kg}$. In Table 4 is a comparison on the vehicle range performance with a single Li-ion battery or the dual-battery solutions. It shows that the dual-battery solutions with this expected Li-air resistance will have a big advantage than the one with only a Li-ion battery while the weight ratio selection is also essential. Besides, extra tests have been carried out in the EPA Federal Test Procedure and Japan 10-15 mode driving cycle. The outcomes have proved the applicability of our final resistance and power selection for the Li-air battery.

\section{Conclusion}

Thus far we discussed the impact on weight and range upon combining Li-ion and Li-air battery technology in a battery system. We determined the resistance of Li-air cell at $0.015 \Omega$ as a minimal target. The power density was found to be in the range of $65 \mathrm{~W} / \mathrm{kg}$. This power level is suitable for the daily driving conditions in cities or towns where the continuous speed is limited and during driving there is time for Li-ion battery to be recharged. In comparison to the

TABLE IV. RANGE COMPARISON

\begin{tabular}{|c|c|c|c|}
\hline & $\begin{array}{c}\text { Single Li-ion } \\
\text { battery }\end{array}$ & $\begin{array}{c}\text { Dualbattery: } \\
\text { A random case }\end{array}$ & $\begin{array}{c}\text { Dualbattery: Optimized } \\
\text { case }\end{array}$ \\
\hline \multirow{2}{*}{ Condition } & Set 9 & Set 6 & Set 1 \\
& N/A & $\mathrm{R}=0.015 \Omega$ & $\mathrm{R}=0.015 \Omega$ \\
\hline NEDC $(\mathrm{km})$ & 190 & 404 & 670 \\
\hline HWFET $(\mathrm{km})$ & 175 & 242 & 575 \\
\hline
\end{tabular}

singleLi-ion system the vehicle range can be enhanced significantly. The power density should be further improved if a drive on the expressway is required.

Weight ratio distribution between batteries is also investigated. All weight considerations are done on the system level. It will result in different answers under diverse driving targets and Li-air battery's power levels. Hence it's significant to find an optimal weight ratio during a dual-battery system design. Situations in a less battery weight and stricter driving cycles can also be surveyed in the future. 


\section{Acknowledgment}

The research is well supported by AVL LIST GmbH. Special thanks to Thomas Traußnig, Peter Krabband Volker Hennige in Global Battery Team who have provided a lot of valuable guidance and advice.

\section{References}

[1] G.Girishkumar, B.McCloskey, A. C.Luntz, S. Swanson, and W. Wilcke, "Lithium-Air Battery: Promise and Challenges,'J. Phys. Chem. Lett., 2010, 1, 2193-2203.

[2] J.Christensen, , P.Albertus,R. S.Sanchez-Carrera, T. Lohmann, B. Kozinsky and R. Liedtke, "A Critical Review of Li/Air Batteries", Journal of The Electrochemical Society, 159 (2) R1-R30 (2012).

[3] A.Kraytsberg andY.Ein-Eli,"Review on Li-air batteries-Opportunities, limitations and perspective", Journal of Power Sources, 196 (2011) 886-893.

[4] Smart battery control system for electric vehicles. http://www.superlib.eu/

[5] S.Monaco, F.Soavi andM.Mastragostino, "Role of Oxygen Mass Transport in Rechargeable Li/O2 Batteries Operating with Ionic Liquids", J. Phys. Chem. Lett., 2013, 4, 1379-1382.

[6] V. Hennige, P. Prenninger, T. Traußnig, H. Stütz, A. Lukacs and C. Fink,Poster Presentation: "Adaption approaches of Li/air battery technology for automotive industry", Transport Research Arena, 14-17th April 2014, Paris La Défense, France.

[7] LABOHR. http://cordis.europa.eu/result/rcn/57482_en.html

[8] T.Traußnig, A.Lukacs,H. Stütz and V. Hennige, Poster Presentation: "Design approaches for future Li/air battery packs in the automotive field", 5. Fachtagung Kraftwerk Batterie, Aachen, Deutschland,2013. 